www.jmscr.igmpublication.org

Impact Factor 5.244

Index Copernicus Value: 83.27

ISSN (e)-2347-176x ISSN (p) 2455-0450

crossref DOI: _https://dx.doi.org/10.18535/jmscr/v4i10.60

Journal Of Medical Science And Clinical Research

\title{
Estimation of Salivary Glucose, Total Proteins, and Albumin in Children with Type 1 Diabetes Mellitus
}

\author{
Authors \\ Reem A.Abdel Aziz ${ }^{1 \S}$, Doaa M. Mahrous ${ }^{2}$, Gamal B. Mohammed ${ }^{3}$, Salama R.Abd El- \\ Rehem $^{4}$, Islam A.Abd El-Wahab ${ }^{5}$ \\ 1,2,3,5 Department of Pediatrics, Faculty of Medicine, Minia University, Egypt \\ ${ }^{4}$ Department of Clinical-pathology, Faculty of Medicine, Minia University, Egypt \\ Email: 2doaamahrous5@yahoo.com,3nashogo@yahoo.com, ${ }^{5}$ mahamahmoud851@yahoo.com \\ ${ }^{\S}$ Corresponding Author \\ Reem A. Abdel Aziz \\ Department of Pediatrics, Faculty of Medicine, Minia University, Egypt \\ Email: reemabdelsalam3@gmail.com
}

Abstract
Aim of the work: is to measure salivary glucose, protein levels and albumin in children with type 1 diabetes
mellitus (TIDM) and to compare and correlate these levels with their serum levels.
Methods: our study included 60 diabetic children were subjected to serum glucose, total protein, albumin and
hemoglobin Alc, in addition to salivary glucose, total protein and albumin and 20 apparently healthy control
children.
Results: there was a significant correlation between serum glucose and salivary glucose in the diabetic
children.
Conclusion: Salivary glucose can be a noninvasive, easy, cheap and not time consuming tool for monitoring
blood glucose in diabetic patients.
Keywords: Salivary Glucose, Proteins, Albumin.

\section{Introduction}

Diabetes mellitus (DM) is an endocrine disease characterized by a shortfall in the production of insulin with consequent alteration of the process of assimilation, metabolism and balance of blood glucose concentra$\operatorname{tion}^{[1]}$.

T1DM is a multi factorial disorder that arises following the autoimmune destruction of insulin producing pancreatic B-cells, leading to severe hyperglycemia necessitating the need for exogenous insulin replacement on a lifelong basis ${ }^{[2]}$.

Saliva is considered to be a reliable diagnostic fluid that can replace blood tests in monitoring a number of both oral and systemic diseases. Several aspects of saliva make this fluid one of the top priority biomedical research topics of the $21^{\text {st }}$ century ${ }^{[3]}$.

Monitoring people with diabetes involve repeated estimations of plasma glucose either by finger pricks or by intravenous blood sampling. Hence, a noninvasive procedure for glucose measurements would be most 
precious under the circumstances; Saliva has long been viewed as unique yet complex body fluids, like plasma or serum. Saliva is easy to collect by noninvasive methods and preservation is inexpensive. The diagnostic value of saliva lies in its components, flow and structure of the gland ${ }^{[4]}$.

The aim of this study is to measure salivary glucose, protein levels and albumin in children with type 1 diabetes mellitus (T1DM) and to compare and correlate these levels with their serum levels.

\section{Methods}

\section{Study Design:}

- This is a Case control prospective study.

\section{Population:}

- This study was carried on 80 children who were divided into two groups:-

$>$ Group 1: Included 60 children who are diabetic patients according to standard American Diabetes Association criteria ${ }^{[7]}$, they had regular follow up in the pediatric diabetes and endocrinology outpatient clinic, Minia University. They were collected during the period from January 2015 to December 2015. Informed written consents were obtained from their parents for their participation in the study.

Group 2: included 20 apparently healthy children matched sex and age with the diabetic patients as controls. The age of both groups ranged from 5 to 15 years.

Presence of chronic illness rather than diabetes (Chronic autoimmune hepatitis, chronic hematologic disorders, prolonged malnutrition, cancer), presence of oral cavity diseases such as: oropharyngeal candidiasis, oral bacterial infections: as periodontitis, dental Carries, oral viral infections, refusal to participate in the study and age younger than 5 years were excluded from our study.

All studied groups were subjected to: full history taking; duration of DM, dose of insulin, types and frequency of insulin administration, family history of DM, history of any other diseases and clinical examination including oral and dental examination.

\section{Samples collection and storage}

All patients were advised to be fasting till both blood and salivary samples were collected,the saliva was collected by spitting method, for collection of saliva, the patients were asked to spit into a sterile container. The collected saliva examined for glucose, total protein and albumin estimation.

All blood samples were collected immediately after salivary samples in the same sitting, $3 \mathrm{ml}$ of venous blood was withdrawn and examined for glucose, total protein and albumin and $\mathrm{HbA} 1 \mathrm{c}$

\section{Laboratory investigations}

Saliva was examined for glucose level (by glucose oxidase-peroxidase (GOD-POD) method, End point), Total Protein level (by Biuret method) ${ }^{[5]}$ and Salivary Albumin (bromocresol green (BCG) dye method) ${ }^{[6]}$. Serum glucose, Total Protein and Albumin levels were measured using the same technique as saliva. Glycated Hemoglobin was assessed using resin column chromatography. kit contents were supplied by TECO DIAGNOSTICS, California, USA

\section{Statistical Methods}

The data were encoded, entered and preceded on computer using SPSS (statistical program for social science, version 11.0). Figures were done using Microsoft Office

Quantitative data were presented as mean \pm standard deviation (SD). while qualitative data were presented as frequency distribution.

\section{Statistical analysis was carried out using the following tests:}

1. Independent sample t test: compares the means between two unrelated groups on the same continuous, dependent variable. 
2. Paired sample t test: compares the means of two variables for a single group. The procedure computes the difference between values of the two variables for each case and tests whether the average differs from 0 .

3. Chi square tests: used to determine whether there is a significant difference between the expected frequencies and the observed frequencies in one or more categories.

\section{Results}

- This study included 80 children who were divided into two groups:-

> Group 1: included 60 children who are diabetic patients according to standard American Diabetes Association criteria ${ }^{[7]}$.

Group 2: (control group): included 20 apparently healthy children matched sex and age with the diabetic patients. They have regular follow up in the pediatric diabetes and endocrinology outpatient clinic, Minia University. They were collected during the period from January 2015 to December 2015.

The demographic data of the studied groups are summarized in (table 1).

The diabetic group had a highly significant higher levels of serum glucose and hemoglobin A1c than the control group as $\mathrm{P}<0.001$, while there were no significant difference between the diabetic and the control groups regarding the level of serum total protein and serum albumin (table 2). The diabetic patients had highly significant higher levels of salivary glucose, salivary total protein and salivary albumin than the control group as $\mathrm{P}<0.001$ (table 3).

There was a highly significant positive correlation between serum glucose and salivary glucose in both diabetic and control groups where, and a highly significant positive correlation between HbA1c and salivary glucose in diabetic group only $(\mathrm{r}=0.556$ and $\mathrm{P}<0.001)$ but no significant correlation between HbA1c and salivary glucose in control group where ( $\mathrm{r}=0.226$ and $\mathrm{P}=0.338)$ (tables 4,5$)$ (figures 1,2$)$.

Table (1) : Demographic data of the diabetic and the control groups.

\begin{tabular}{|l|c|c|c|}
\hline & $\begin{array}{c}\text { Diabetic group } \\
(\mathrm{n}=60)\end{array}$ & $\begin{array}{c}\text { Control group } \\
(\mathrm{n}=20)\end{array}$ & P value \\
\hline $\begin{array}{l}\text { Age (years) } \\
\text { Range } \\
\text { Mean } \pm \text { SD }\end{array}$ & $\begin{array}{c}(5-15) \\
10.53 \pm 3.01\end{array}$ & $10.5 \pm 3$ & 0.966 \\
\hline Sex & & & \\
Male & $34(56.7 \%)$ & $11(55 \%)$ & 0.896 \\
Female & $26(43.3 \%)$ & $9(45 \%)$ & \\
\hline Residence & & $9(45 \%)$ & 0.302 \\
Rural & $28(46.7 \%)$ & $11(55 \%)$ & \\
Urban & $32(53.3 \%)$ & $12(60 \%)$ & 0.518 \\
\hline Family history of DM & & $8(40 \%)$ & \\
\hline -Ve & & & \\
+ Ve & $32(53.3 \%)$ & & \\
\hline
\end{tabular}




\section{JMSCR Vol||04||Issue||10||Page 13163-13170||October}

Table (2): Comparison between Serum Levels of Glucose, Total Protein, Albumin and HbA1c in both diabetic Patients and Control Groups

\begin{tabular}{|c|c|c|c|}
\hline 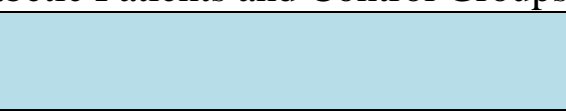 & $\begin{array}{l}\text { Diabetic group } \\
\quad(n=60)\end{array}$ & Control group $(n=20)$ & $P$ value \\
\hline $\begin{array}{l}\text { Serum glucose }(\mathrm{mg} / \mathrm{dl}) \\
\text { Range } \\
\text { Mean } \pm \text { SD }\end{array}$ & $\begin{array}{c}(136-541) \\
286.6 \pm 94.65\end{array}$ & $\begin{array}{c}(71-99) \\
86.7 \pm 8.57\end{array}$ & $<0.001 *$ \\
\hline $\begin{array}{l}\text { Serum total protein }(\mathrm{g} / \mathrm{dl}) \\
\text { Range } \\
\text { Mean } \pm \mathrm{SD}\end{array}$ & $\begin{array}{c}(6-8.1) \\
6.64 \pm 0.55\end{array}$ & $\begin{array}{c}(6.1-8.1) \\
6.86 \pm 0.73\end{array}$ & 0.158 \\
\hline $\begin{array}{l}\text { Serum albumin }(\mathrm{g} / \mathrm{dl}) \\
\text { Range } \\
\text { Mean } \pm \mathrm{SD}\end{array}$ & $\begin{array}{c}(3.6-4.8) \\
4.07 \pm 0.33\end{array}$ & $\begin{array}{c}(3.6-4.8) \\
4.08 \pm 0.35\end{array}$ & 0.924 \\
\hline $\begin{array}{l}\text { Hb A1c }(\%) \\
\text { Range } \\
\text { Mean } \pm \text { SD }\end{array}$ & $\begin{array}{c}(6.7-14.7) \\
9.94 \pm 2.28 \\
\end{array}$ & $\begin{array}{c}(4-5.5) \\
4.91 \pm 0.38 \\
\end{array}$ & $<0.001 *$ \\
\hline
\end{tabular}

Table (3): Comparison between Salivary Glucose, Total Protein, Albumin in both diabetic Patients and Control Groups

\begin{tabular}{|l|c|c|c|}
\hline & $\begin{array}{c}\text { Diabetic group } \\
(\mathrm{n}=60)\end{array}$ & Control group $(\mathrm{n}=20)$ & P value \\
\hline $\begin{array}{l}\text { Salivary glucose }(\mathrm{mg} / \mathrm{dl}) \\
\text { Range }\end{array}$ & $(2.1-5.6)$ & $(0.4-1.15)$ & $<0.001^{*}$ \\
Mean \pm SD & $3.52 \pm 0.92$ & $0.76 \pm 0.23$ & \\
\hline & & & $<0.001^{*}$ \\
Salivary total protein $(\mathrm{g} / \mathrm{dl})$ & $(167-191)$ & $(125-140)$ & \\
$\begin{array}{l}\text { Range } \\
\text { Mean } \pm \text { SD }\end{array}$ & $177.15 \pm 6.05$ & $131.6 \pm 4.84$ & $<0.001^{*}$ \\
\hline $\begin{array}{l}\text { Salivary albumin }(\mathrm{g} / \mathrm{dl}) \\
\text { Range } \\
\text { Mean } \pm \text { SD }\end{array}$ & $(75.5-98)$ & $(52-67)$ & \\
\hline
\end{tabular}

Table (4): Correlation between Serum glucose and HbA1c with salivary glucose in diabetic group

\begin{tabular}{|l|c|c|}
\hline \multirow{2}{*}{ Diabetic group } & \multicolumn{2}{|c|}{ Salivary glucose } \\
\cline { 2 - 3 } & $\mathrm{r}$ & $\mathrm{P}$ value \\
\hline Serum glucose & 0.715 & $<0.001^{*}$ \\
\hline Hb A1c & 0.556 & $<0.001^{*}$ \\
\hline
\end{tabular}

Table (5): Correlation between serum glucose and HbA1c with salivary glucose in control group

\begin{tabular}{|l|c|c|}
\hline \multirow{2}{*}{ Control group } & \multicolumn{2}{|c|}{ Salivary glucose } \\
\cline { 2 - 3 } & $\mathrm{r}$ & P value \\
\hline Serum glucose & 0.625 & $0.003^{*}$ \\
\hline Hb A1c & 0.226 & 0.338 \\
\hline
\end{tabular}


Figure 1: Correlation between Serum glucose and salivary glucose in diabetic group.

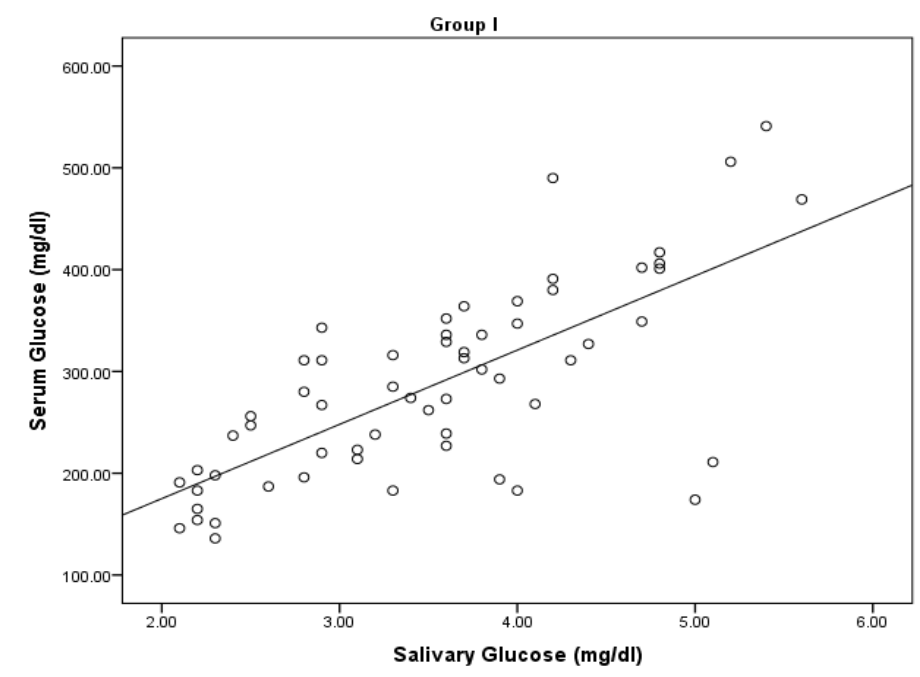

Figure 2: Correlation between HBA1c and Salivary glucose in diabetic group.

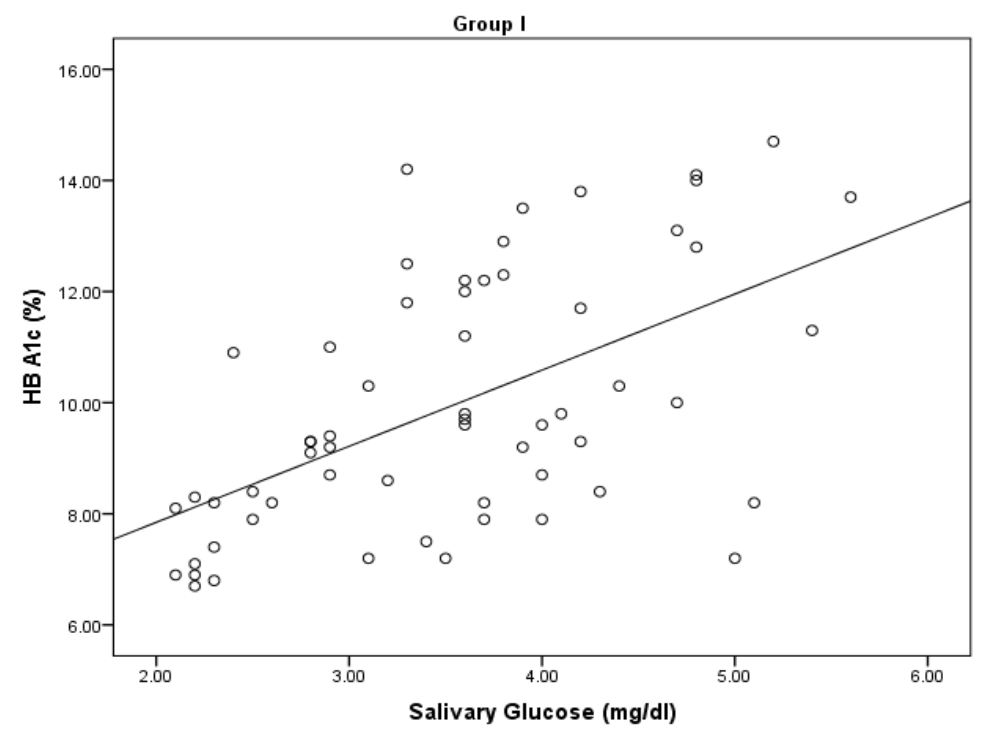

\section{Discussion}

Type 1 diabetes mellitus (DM) is a multisystem disease with both biochemical and anatomic/structural consequences. It is a chronic disease of carbohydrate, fat, and protein metabolism caused by the lack of insulin, which results from the marked and progressive inability of the pancreas to secrete insulin because of autoimmune destruction of the beta cells ${ }^{[8]}$.

The usual technique to estimate for blood glucose level by venipuncture is traumatic, especially in children leading to anxiety and trauma ${ }^{[9]}$, Hence the need for an alternative noninvasive technique is required.

As a diagnostic fluid, saliva offers distinctive advantages over serum because it can be collected noninvasively by individuals with modest training. Furthermore, saliva may provide a cost effective approach for the screening of a large population ${ }^{[10]}$.

Therefore the current study aimed to measure salivary glucose, protein levels and albumin in children with type 1 diabetes mellitus (T1DM) and to compare and correlate these levels with their serum levels.

This current study was carried out on 80 children, classified into 2 groups: Diabetic group: Included 60 diabetic children with an already established diagnosis of T1DM, Control group: Included 20 apparently healthy children matched sex and age with the diabetic patients.

Both salivary and serum samples were obtained at the same time to avoid any change in the glucose level. 
The results of our study showed that the diabetic group had a highly significant higher levels of serum glucose and hemoglobin A1c than the control group $(\mathrm{P}<0.001)$, while there were no significant difference between the diabetic and the control groups regarding the level of serum total protein and serum albumin $(\mathrm{P}$ $>0.05$ ) as shown in Table (2) which suggests that diabetic group had an average elevated blood glucose concentration over an extended time period but in the control group had normal blood glucose concentration over an extended time period suggesting that the control group are non-diabetic ${ }^{[11]}$.

The results of our study showed that the salivary glucose levels in T1DM group were significantly higher compared to control group ( $\mathrm{P}<0.001)$ as shown in Table (3). These results were consistent with the studies done by ${ }^{[12,13,14]}$ who found that the salivary glucose levels in T1DM group were significantly higher compared to control group. Glucose is a small molecule that can diffuse through the semi permeable membrane and can be detected in saliva especially when the blood sugar levels are elevated. Also, alteration in the basement membrane of the salivary glands which leads to leakage of glucose in saliva, any alteration in the basement membrane of blood vessels may cause increased transport of glucose into saliva ${ }^{[13]}$.

The results of our study revealed that levels of salivary total proteins were significantly higher in T1DM group as compared to control group as $\mathrm{P}<0.001$ ) as shown in Table (3). These results were in accordance with the studies done by ${ }^{[12,1,15]}$. They found that salivary total proteins were significantly higher in T1DM. The salivary total protein is a vital component of saliva, predominantly comprising proline-rich proteins. The levels of proteins depend on the salivary flow rate, as the flow rate decreases the protein levels increases. The salivary flow rate in diabetes is also diminished, which is related to salivary viscosity and foam. Viscosity otherwise called "spinbarkeit" and foam are reflected by the higher levels of proteins ${ }^{[16]}$. However, few studies done by ${ }^{[17]}$ showed that there were no significant difference in the levels of salivary total proteins between the diabetic patients and controls. This contradiction can be explained by the fact that the studies might have incorporated different methodology and metabolic control status of the patients.

The results of our study revealed that level of salivaryalbumin was significantly higher in T1DM group as compared to control group ( $\mathrm{P}<0.001)$ as shown in Table (3).

These results are in accordance with the studies done by ${ }^{[12,1,15]}$ They found that salivaryalbumin was significantly higher in T1DM.

The elevated levels of salivary albumin could be explained with abnormal binding of serum proteins to salivary gland basement membranes may be a reflection of increased permeability; this basement membrane permeability is often associated with diabetes, which leads to increased passage of proteins, IgG, albumin, and polyvalent immunoglobulin's from exocrine glands into their secretions ${ }^{[18]}$.

However, few studies done by ${ }^{[19]}$ showed that there were no change in salivary albumin levels in T1DM compared to controls, This conflict could be explained by the different type of methodology and the technique of saliva examination included in their controls.

In our study we found that HbA1clevelsindiabeticpatientscorrelated positively and highly significant with their salivary glucose level( $\mathrm{r}=0.556$ and $\mathrm{P}<0.001)$ as shown in Table (4) and Figure (2), which suggests that diabetic group had an average elevated blood glucose concentration over an extended time period but in the control group had normal blood glucose concentration over an extended time period suggesting that the control group are non-diabetic ${ }^{[11]}$.

These results are in accordance with the studies done by ${ }^{[20,21]}$ who reported that HbA1 clevelsin diabetic patients correlated positively and significantly with their salivary glucose level.

In our study, There were a positive highly significant correlation observed between salivary and serum glucose levels in the diabetic group ( $\mathrm{r}=0.715$ and $\mathrm{P}<0.001)$ as shown in Table (4), Figure (1) and also a positive highly significant correlation observed between salivary and serum glucose levels in the control group $(r=0.625$ and $\mathrm{P}=0.003$ ) as shown in Table (5) and Figure (3). 
This finding is in agreement with the studies doneby ${ }^{[12]}$, The study included 30 diabetes patients with an already established diagnosis of T1DM, and a control of 30 healthy individuals. were taken from District General Hospital Gulbarga and Rudrawadi's Diabetic Care Center Gulbarga, Also our results were in agreement with the studies done by ${ }^{[13,14,20]}$. They found that there were a positive significant correlation observed between salivary and serum glucose levels in T1DM and control group.

In contrary to our study, studies obtained by Gheena et al, and Bakianian et al. concluded that there were no correlation between salivary and serum glucose levels ${ }^{[1,22]}$. This conflict could be explained by the different type of methodology and the technique of saliva examination included in their study.

\section{Conclusion}

Salivary glucose can be a noninvasive, easy, cheap and not time consuming tool for monitoring blood glucose in diabetic patients; can be used as a general screen for prediabetes and undiagnosed diabetes. Also, it can be used for follow-up in diabetic patients instead of traumatic usual method.

\section{List of abbreviations:}

GOD- POD :glucose oxidase-peroxidase

BCG : bromocresol green

\section{Declarations:}

Ethics: Informed parental consent was obtained to be eligible for enrollment into the study. The study was done according to the rules of the Local Ethics Committee of Faculty of Medicine, Minia University, Egypt.

\section{Acknowledgement}

We express our gratitude to all staff members of our pediatric department especially the Diabetic Outpatient Clinic.

\section{Funding:}

The research was funded by the researchers as employees of El Minia University.

This research did not receive any specific grant from funding agencies in the public, commercial, or not-forprofit sectors.

\section{Availability of data and Materials}

Not applicable.

\section{Competing interests}

All authors declare that they have no competing interests.

\section{References}

1. Gheena S., Chandrashekhar T and Ramani P. Salivary characteristics of diabetic children. Braz J Oral Sci. 2011; 10: 93-7.

2. Amutha A., Thai K and Vishwanathan M., Childhood and adolescent onset Type 1 diabetes in India. J Med Sci. 2013; 1(1): 46-53.

3. Malamud D . Saliva as a diagnostic fluid. Dent Clin North Am. 2011; 55 (1): 159- 78.

4. Hedge A, Shenoy R, D'Mello P, Smitha A, Tintu A and Manjrekar P. Alternative markers of glycemic status in diabetes mellitus. Biomed Res. 2010; 21: 252-6.

5. Thomas L. Clinical Laboratory Diagnostics. 1st ed. Frankfurt: TH Books Veriagsgessellchaft; 1998; 131-7. 
6. Tietz NW. Text Book of Clinical Chemistry. Philadelphia, USA: W.B. Saunders.1986; 231-46.

7. American Diabetes Association. Standards of Medical Care in Diabetes: Abridged for Primary Care Providers. Clinical Diabetes. 2015; 33: 2.

8. Pilia S, Casini MR and Cambuli VM. Prevalence of Type 1 diabetes autoantibodies (GAD and IA2) in Sardinian children and adolescents with autoimmune thyroiditis. Diabet Med. 2011 Aug.; 28(8): 896-9.

9. Panchbhai AS. Correlation of salivary glucose level with blood glucose level in diabetes mellitus. J Oral Maxillofac Res. 2012; 3(3): 3-3.

10. Krishna BA, Ashalatha G, Baghirath VP, RajaniKanth AV and Malathi N. Saliva as a diagnostic biofluid-review. J OrofacSci 2010; 2: 66-70.

11. American Diabetes Association. Standards of medical care in diabetes. Diabetes Care. 2011; Jan. 34 (1): 11-61.

12. Shahbaz S, Katti G, Ghali SR, Katti C, Diwakar DD and Guduba V. Salivary alterations in type 1 diabetes mellitus patients: Salivary glucose could be noninvasive tool for monitoring diabetes mellitus. Indian J Dent Res. 2014; 25: 420.

13. Nagalaxmi V and Priyanka V. Can saliva be a marker for predicting type I diabetesmellitus?-a pilot study.J Indian Acad Oral Med Radiol. 2011; 23(4): 579-82.

14. Iqbal S, Asad S, Farhat K and Fareeha B. Correlation between salivary glucose level and gingivitis in patients with diabetes. J Islamabad Med Dent. 2011; 110-3.

15. Nawalkar A and Bhoweer A. Alterations in whole saliva constituents in patients with diabetes mellitus and periodontal disease. J Indian Acad Oral Med Radiol. 2011; 23: 498-501.

16. Panchbhai AS, Degwekar SS and Bhowte RR. Estimation of salivary glucose, salivary amylase, salivary total protein and salivary flow rate in diabetics in India. J Oral Sci. 2010; 52: 359-68.

17. Belazi MA, Galli-Tsinopoulou A, Drakoulakos D, Fleva A andPapanayiotou PH. Salivary alterations in insulin-dependent diabetes mellitus. Int J Paediatr Dent 1998; 8: 29-33.

18. Meurman JH, Rantonen P, Pajukoski H and Sulkava R. Salivary albumin and other constituents and their relation to oral and general health in the elderly. Oral Surg. Oral Med. Oral Pathol. Oral Radiol. Endod. 2002; 94: 432-8.

19. Vaziri PB, Vahedi M, Abdollahzadeh SH, Abdolsamadi HR, Hajiloori $M$ and Kasraee SH. Evaluation of salivary albumin in diabetic patients. Iran J Public Health. 2009 ; 38: 54-9.

20. Abikshyeet P, Ramesh V and Oza N. Glucose estimation in the salivary secretion of diabetes mellitus patients. Diabetes MetabSyndrObes. 2012; 5: 149-54.

21. Satish BN, Srikala P, Maharudrappa B, Awanti SM, Kumar P and Hugar D. Saliva: A tool in assessing glucose levels in Diabetes Mellitus. J Int Oral Health. 2014 Apr.; 6(2): 114-7.

22. BakianianVaziri P, Vahedi M, Mortazavi H, AbdollahzadehSh and Hajilooi M. Evaluation of salivary glucose, IgA and flow rate in diabetic patients: A case-control study. J Dent (Tehran). 2010; 7: 138. 